Viewpoint

\title{
Debating contemporary urban conflicts: A survey of selected scholars
}

\author{
Alvaro Sevilla-Buitrago *,1 \\ Departamento de Urbanística y Ordenación del Territorio, Universidad Politécnica de Madrid, 4 Avda. Juan de Herrera, Madrid 28040, Spain
}

\section{A R T I C L E I N F O}

\section{Article history:}

Received 27 June 2012

Accepted 13 August 2012

Available online 13 September 2012

\section{Keywords:}

Urban conflict

Urban planning

Urban geography

Urban sociology

Urban anthropology

Social inequality

\begin{abstract}
A B S T R A C T
This survey presents the results of a questionnaire sent to a list of key scholars and professionals in fields related to urban processes and planning - town planning, geography, sociology, architecture and anthropology. The survey raised four simple, straightforward questions. What are the most pressing conflicts with regard to contemporary cities? What are the main fields of action for solving them? How can your discipline contribute with respect to this task? Could you mention an intervention that could serve as an example of that line of work? The response represents a plural and multidisciplinary perspective on contemporary urban issues from which a series of research and intervention perspectives emerges.
\end{abstract}

(c) 2012 Elsevier Ltd. All rights reserved.

\section{Introduction}

Perhaps one of the most effective ways to measure the pulse, aspirations and scope of scientific work is to analyze the questions it raises. Given the bases of urbanism and planning in applied knowledge and their goals of resolving specific, material problems, that analysis could be extended to identify and examine the contradictions our efforts target. How do disciplines oriented towards analyzing urbanization and territory model the object of their work (Batty, 2012; Beauregard, 2010; Pacione, 2005, pp. 22-42)? What processes do we term as 'conflicts' and why? What tools can we use to analyze those processes? How do our own scientific and political biases determine this perception, and how are those biases connected to everyday experience of those contradictions in the city? A brief examination of the enormous range of positions

\footnotetext{
* Tel.: +34 639605906; fax: +34 913366534.

E-mail address: alvaro.sevilla@upm.es

1 Respondents: Adrian Atkinson (Technische Universität Berlin, DUP Associates), Pedro Bannen (Pontificia Universidad Católica de Chile), Robert Beauregard (Columbia University), Mike Davis (University of California), Simin Davoudi (Newcastle University), Manuel Delgado (Universitat de Barcelona), Jean-Pierre Garnier (Centre National de la Recherche Scientifique, Paris), Kanishka Goonewardena (University of Toronto), Mark Gottdiener (University at Buffalo), Peter Hall (University College London), Gita Kewalramani (University of Mumbai), Rob Krier (KK Gesellschaft von Architekten $\mathrm{mbH}$ ), Vittorio Magnago Lampugnani (Eidgenössische Technische Hochschule Zürich), Luigi Mazza (Politecnico di Milano), Alberto Mioni (Politecnico di Milano), Alain Musset (École des Hautes Études en Sciences Sociales, Paris), Zaida Muxí (Universitat Politècnica de Catalunya), Michael Pacione (University of Strathclyde), Nuno Portas (Universidade do Porto), Ivor Samuels (University of Birmingham), Saskia Sassen (Columbia University), Jianfa Shen (The Chinese University of Hong Kong), Michael Sorkin (The City University of New York), Max Welch Guerra (Bauhaus Universität Weimar), Sharon Zukin (The City University of New York).
}

and publications labeled as urban studies gives an idea of the richness and breadth of approaches to these theoretical, empirical and technical questions (Davies \& Imbroscio, 2010; Hubbard, 2006, pp. 9-58; Paddison, 2001). However, to what extent does that diversity contribute to effectively dealing with and resolving the conflicts that give rise to it? In other words, does the proliferation and increasing prominence of urban studies point to progress in the order of knowledge and practice or, on the contrary, does it lead to a dispersion of modes of understanding, which, instead of helping us pinpoint and deal with the contradictions of urbanization, make them difficult to identify and define? This convergence of doubts led to the collective idea of preparing an international questionnaire to explore the opinions of a significant group of thinkers in a number of disciplines related to the city and to the analysis and government of their processes.

Even though a great deal of research in the field of urban studies is devoted to analyzing specific conflicts in particular cities and processes, the lack of a general and systematic approach to this issue is significant and, perhaps, reveals the inner constitution - and shortcomings - of the discipline. Moreover, the most ambitious attempts to address the topic often focus on aspects that are presented as an excess or alteration of the 'normal' urban order, as instabilities or deviations from the supposed state of territorial, economic or environmental balance. Of course, phenomena such as social (e.g., see Le Galès, 2002; Urban Studies, 2010) or political (e.g., see Bollens, 2000; Flint, 2006) conflicts - often involving violence or crime (e.g., Bertho, 2009; McClain, 2001; Winton, 2004) - and the urban nexus of the environmental crisis (e.g., see the special issues of Cities, 1996, 2011) or economic decline (e.g., Glaeser \& Gyourko, 2005; Sugrue, 2005) have often monopolized researchers' interests. It is, nevertheless, much more difficult to 
find contributions articulating these particular conflicts or to attempt to trace their common ground in order to obtain a wider, systemic picture of the connections and synergies between the multiple layers of urban conflict (e.g., see Brenner \& Theodore, 2002). Meanwhile, the focus on 'exceptional' imbalances in the urban order hinders the identification and understanding of the variegated context of micro-conflicts embedded in everyday urban life, an archipelago of contradictions that, indeed, denies the supposed harmony of 'normal' urban regimes - a wider map of conflicts that should invite us to reconsider the politics of urban studies and to reassess their role and project.

The following pages are the result of that endeavor. They present responses given by the academics and professionals consulted regarding four questions that are seemingly simple but are really quite challenging to answer:

1. Although all urban formations are, in themselves, a network of contradictions - which vary considerably depending on their locations and social and political contexts - what in your opinion is the most pressing conflict involving contemporary cities, one that most deserves investigation or to which you personally have devoted your greatest energy?

2. What are the main fields of action for solving this conflict, and which channels should be used to direct those efforts?

3. How can your discipline contribute with respect to this task?

4. Could you mention a policy, program, plan or even a theoretical intervention that could serve as an example of that line of work?

Although these may appear to be innocent questions - as is in fact suggested by several of the authors taking part in the survey - they are important in theoretical, practical, scientific and political terms. Crucially, I believe that the formulation of those questions in such basic terms may be an opportunity for finding common ground in a range of disciplines that take urban issues as their object of concern - i.e., for rethinking a space of cooperation that, as some of the contributors suggest, has long become a terrain vague, somewhere between the fronts of the academic trench war waged during the last few decades. Unfortunately, despite the habitual and mechanical allusions to multidisciplinarity, the tendency towards scientific hyper-specialization and the magnificent capacity for sophisticating our discourses takes us further not only from the response to these generic approaches but also further from the mere wish to formulate them and collaborate in resolving them (INURA (International Network for Urban Research \& Action), 2003). It appears clear that as university departments prosper and proliferate under these academic trends, civil society will eventually stand to lose. We hope that this survey will contribute to reopening the debate about these simple but urgent issues.

Those responding to the questionnaire include a diverse group of relevant thinkers in their respective fields and contexts. Here, urbanists and planners share space with sociologists, architects, geographers and anthropologists, specialists in areas that we consider essential for the integral and reflective comprehension of urban processes. No doubt there will be other disciplines that claim to take part in this debate, and in this sense, we hope this will be merely a first step in opening up the arena to new contributions. However, if every selection has its shortcomings, we think it essential to carry out an exercise of self-criticism and mention two whose structural nature renders them particularly obvious. In an academic environment aware of feminist and post-colonial perspectives, it is difficult to defend the legitimacy of a sample in which women and participants from the Global South continue to be in the minority. Without doubt, the final result would be much more complex if more voices from both these segments had been included. The list initially proposed was practically gender-balanced, with a much higher proportion of candidates from the Global South. However, on many occasions contact with candidates could not be made. This shortcoming could serve as an invitation to continue the dialogue by means of new contributions that would complete, diversify or even refute the opinions expressed herein.

Readers will find four responses from each participant. These responses take a heterogeneous form in terms of extension and depth. Some authors asked to illustrate their texts with images, proposing that such illustrations would contribute to the synthetic transmission of their opinions, in particular, with respect to solutions to the problems posed. On some occasions, the persons interviewed preferred to use a different structure, by giving general responses, or to transmit their opinions under a global heading or title. Finally, one participant refused to respond to a specific question, an attitude that clearly indicated a critical stance with regard to the nature of the question or possible responses.

\section{Responses}

\section{Adrian Atkinson, Technische Universität Berlin, DUP Associates}

1. Intensive engagement of the world's population with immediate concerns in an ever faster-moving consumerist world has obscured meaningful thought about the future in the minds of urban planners, activists and theorists. The current crisis means economic crisis with, apparently, almost nobody prepared to accept its origin; hence, there is no meaningful search for deeper resolutions.

There is talk and talk and talk about 'global warming,' but no meaningful policies or action to deal with it are, however, in view. In reality, the only practical way to stem runaway global warming is to reduce and soon stop burning fossil fuel. This seems to be unthinkable because our whole world depends entirely on increasing consumption of fossil fuel. And yet it is now almost universally recognized that we are approaching the limits of the exploitation of fossil fuel and that 'peak oil' is upon us. This is good news from the point of view of global warming because we will be forced to use less fossil fuel. However, in the light of the coming decline in energy resources, the present 'economic crisis' is but a shadow of things to come.

2. In the coming decades, we will see the era of cities disappear. If there were in any way recognition of what is to come (and, in terms of the response to curb global warming, what should be done), then planning would come back into its own from the situation today where it has been pushed into the background; we are merely reacting to immediate developments. We need to think strategically again about what to do with the reorganization of the spatial distribution and morphology of settlements. Why? Because the decline in energy means the collapse of the global economy in the coming decades and the return of production - and lifestyles - to the local scale. It means the unviability (unsustainability) of large cities with populations emptying out in search of food and work, and with this the necessity of rebuilding local economies as the flow of food and manufactured goods from the other side of the world withers away.

So, even before launching new strategies in planning, we need to think about how to bring food production back to cities and their sub-regions (urban and peri-urban agriculture - UPA) and, thence, developing coherent initiatives to revive variegated local economies that do not just sell goods produced in other places, but actually produce things locally again through participatory Local Economic Development (LED). 
3. The old disciplinary boundaries would not be relevant in the future; much that is today 'professional' will lose its usefulness, and we will need to think and act laterally - in new ways, addressing the real world that will emerge as our global virtual world implodes. 'Urban planners' can still have a role in this endeavor, but only by turning to things they hardly thought about in the past: planning UPA and participatory approaches to LED. Both of these projects are beginning to gain coherence in different ways and in different places. But the understanding of their importance - and hence time and money and educational investment - is as yet extremely weak.

4. Policies relating to the above should be self-evident: promotion of UPA and LED and, strategically, regional planning in the mold of bioregionalism. Few know what any of these mean because the present world paradigm and consciousness are a long, long way from recognizing the challenges we face. But once the real future starts to come into focus, policies and programs to address these challenges may start to fall into place.

\section{Pedro Bannen, Pontificia Universidad Católica de Chile}

1. The most significant conflict in the contemporary city is the paradox that, although the city is increasingly larger, containing a growing segment of the global population, there are fewer and fewer citizens who identify with their city. In the case of Santiago de Chile, with a population of over six million people, whenever the sense of its inhabitants' belonging and identification with the metropolis is studied, the results demonstrate weakened linkages of identity and a perceived lack of any collective project relating to the future of the city.

The last 30 years of urban history in Santiago de Chile demonstrate an astounding level of growth directly associated with the country's economic development, led by Santiago and expressed in its new configuration. Expansive growth at a higher rate than that of the growth of the population, reflecting a five-fold increase in GDP per capita during the same period; growth in urban density and building height within the new central cores of the business districts and affluent neighborhoods; the emergence of large shopping centers extended throughout the urban fabric; combined with elevated levels of social segregation illustrate a scandalous socio-economic distribution. The new city is an uneven geography of opportunities for the different groups of inhabitants.

2. In Chile, the problem points to a structural condition connected both to the country's historical traditions and to the expression of the particular mode of capitalist accumulation that fosters and exacerbates this new configuration. The most effective fields of action appear to require reform of the dominant model, what may well be taken as an index of its current state of crisis. The model of governance, the citizens' voice in the parliament, and the focus placed on local government management are key elements when channeling motivations, representativeness and effective public participation towards reconstituting the city as a high-priority issue of concern and identity.

However, the scale of an urban structure, such as Santiago de Chile and a number of other cities on the continent, demands that this metropolitan phenomenon be understood as the agglomeration of several juxtaposed settlements, in which the opportunity for identity is provided primarily by the spaces that contain the daily activities of the citizens, allowing chances to live, study or work, and to access commodities, leisure activities and services, all within a recognizable and manageable urban territory.
3. Urban and territorial planning plays a key role in conjoining territorial dynamics in a balanced and convincing fashion for all the social factors involved in the generation and configuration of the metropolis. Our discipline is capable of discerning possible future scenarios before they occur, facilitating the driving forces of development and foreseeing possible conflicts between actors with a special concern for the citizenry. However, this project requires a strengthened state that assumes responsibility as a leader of such processes, as a mediator between public and private interests, abandoning its current role as a facilitator for the development of corporate initiatives as an almost exclusive function.

4. One experience in this regard was the case of the Providencia municipality, an urban fragment in the East of Metropolitan Santiago, which in the 1980s took advantage of the high level of investment available for the construction of the underground to open a new branch of the main avenue in the district, configuring a core space within the city and a major element for the structuring axis of Greater Santiago. A meaningful vision of the city, coordination between multiple agents (both public and private) regarding construction, and a citizenry empowered by its dual metropolitan/local functions, provided quality and identity to one of the strongest urban areas in contemporary metropolitan Santiago.

\section{Robert Beauregard, Columbia University}

1. I do not think one can treat all cities as the same. Consequently, any answer to these questions has to distinguish among types of cities; e.g., global vs. national vs. regional cities, rapidly growing vs. declining cities, etc. Two interrelated themes do cut across these categories - growth and the distribution of the consequences of growth. These two functions should not be separated. Cities need to grow so that tax bases expand and new populations can be accommodated, but they should not grow without an equitable distribution of the costs and benefits of growth. This concern, then leads to another central issue, and that is tolerance for others. Cities are places where living with strangers is both necessary and difficult, and particularly difficult when growth without (re)distribution occurs, or decline occurs with only certain people bearing its burdens.

2. These issues can only be addressed with strong, democratic governments that counteract the inherent tendencies of capitalism to produce growth without equality, and governments that tolerate and even nurture civil society.

3. Urban planning can contribute by providing a view of cities that does not reduce them to simply engines of economic growth. Urban Planning can defend the state and civil society and encourage critical perspectives on development.

4. One might begin with a commitment to a 'just city'. Justice is not only a basic value whose pursuit would help to reduce the inequalities, marginalities, and oppressions occurring in cities - the concern with justice can easily be connected to other values such as sustainability, tolerance, and empowerment.

\section{Mike Davis, ${ }^{2}$ University of California}

1. Increasingly violent and broadly sectarian conflict over survival niches in cities. I believe that the almost pandemic development of exclusionary identity-political movements grows directly out of the global employment crisis. As informal survival options have narrowed in the face of population growth and unemployment in so many cities, the use of coercion to

\footnotetext{
${ }^{2}$ Mike Davis did not respond to question 4 (Editor's note).
} 
ration subsistence and reduce competition has been commonplace. Traditional patronage politics, which exchanges small economic opportunities for loyalty in bloc, has been reinforced everywhere by mobilizations of imaginary communities of language, religion, race, ethnicity/national origin, or place.

2. Economic growth producing large numbers of formal-sector jobs is the abstract solution to the involution of the informal urban economy, but prospects in this depression era are now grim. Especially when commodity-export booms in so many countries (like Brazil and South Africa) has gone hand in hand with increasing rural unemployment and urban deindustrialization.

3. We need more case-studies that explore the economic logic of urban sectarian conflict (especially in regard to the organization of the informal economy) in cities such as Mumbai, Karachi, Lagos, or Nairobi. And, of course, we need more comparative analysis, especially between urban regions where sectarian violence has become embedded in the political economy and those cases (most in Latin America, Turkey perhaps) where urban conflict, although it may inherit certain racial and ethnic discriminations, is largely non-sectarian.

\section{Simin Davoudi, Newcastle University}

\section{Cities}

The year 2008 marked a watershed in human history when, for the first time, more than half of the world's population lived in cities. Cities will continue to be a magnet, and their population will rise to $70 \%$ by 2050 . However, there remains a paradox. Cities are praised for being the cradle of civilization, the incubators of advanced culture, the repositories of knowledge and innovation, the engines of economic growth, the centers of cultural and artistic excellence, and the habitats for co-existence of diverse populations. However, cities are blamed for marginalization and exclusion of communities, environmental disasters, pollution and congestion, diseases, insecurity and alienation, unfettered consumption and the specter of global warming. This bifocal vision of the city has triggered conflicting impulses in artistic and literary expressions, scholarly inquiries, design and engineering experimentations, planning endeavors, and political aspirations. Capturing, understanding, and managing cities' relational complexities have preoccupied humankind for centuries. While cities are a plural phenomenon, everywhere they are confronted with questions such as: how to become free of ghettos, gated communities, inequalities, sprawling growth and unsustainable processes? How to enhance the rights to the city and greater participation in urban governance? How to make cities better places for many rather than the few, for the present as well as the future, for humans as well as non-humans? (Davoudi, 2012).

\section{Interpretive planning}

For centuries, people have grappled with the challenge of making cities better places. In recent decades, such efforts have clustered around an activity known as urban planning. In the UK, as in many other countries, planning has grown into a recognizable discipline in social and institutional terms, but its intellectual underpinning has remained ambiguous (Davoudi \& Pendlebury, 2010). This ambiguity has affected the way in which planners have perceived cities and sought urban solutions. For the best part of the twentieth century, the legacy of Euclidean geometry reinforced by a Newtonian view of spatiality dominated planning activities. From this perspective, cities were seen as neutral containers filled with physical objects and functions. They were treated as peopleless, objective, bounded, and scientifically measurable entities. The role of planners was to order cities spatially and temporarily and to create neatly separated categories, represented on two-dimensional, Cartesian maps. The process was seen as linear and rational in which technical evidence produced by experts had an instrumental place (Davoudi, 2006). The intellectual shortcomings and practical limitations of this positivist approach have been subject to growing criticisms, with the most radical one coming from the interpretive tradition. This "conceptualizes space as relational and dependent on the social and cultural process and substances that produce it' (Davoudi, 2011, p. 10). Cities are defined subjectively by people's daily experience of engaging with them; by their perceived spaces of everyday life. Cities are understood not just as 'matters of fact,' but also as 'matters of concern'. Fluidity, contingency, dynamism and simultaneity are key characteristics of the interpretive planning. What drives interpretive planners is the desire not to control cities, but to connect cities' multiple relations. The emphasis is not to reduce cities' complexities, uncertainties and contingencies and multiple connections, but 'to seek opportunities and expand the space for novelty and adventure' (Davoudi, 2011, p. 11).

\section{Manuel Delgado, Universitat de Barcelona}

1. Without doubt, the dynamics of tertiarization, thematization, gentrification, privatization of public space and other forms of attaching priority to exchange value as opposed to use value resulting from the capitalist exploitation of land and the image of cities and resulting phenomena such as the destruction of neighborhoods considered to be insolvent, the massive exclusion of social sectors regarded as undesirable, the perpetual policing and monitoring of social life on streets, the harassment of those who dare to disagree and, in general, the sentencing to death of the popular city. I believe it is of vital importance to deal with something that politicians and planners often ignore - the social consequences of those processes of predation and control. Most of my work as a professor and researcher in the social sciences is dedicated to this, preferably with regard to such specific aspects as the competences of use in public spaces, forms of opposition used by residents, or the relationship between social practices and built-up environments.

2. The foregoing conflicts can only be resolved through large-scale social transformations that would affect both the social system and the economic order that determines it. Until those changes are implemented, all we can do is to pave the way for them in the areas in which we carry out our professional and personal activities.

3. Scientific research and teaching in social and human sciences may and should help us know the processes and structures that affect human life in cities and as a result, obtain information that will contribute to improving it. It goes without saying that we are condemned to come up against constraints imposed by university and scientific policies at the service of institutional and business interests associated with a privileged few, with the sole objective of obtaining political sway and economic benefit. In that case, all that can possibly be done is to become double agents at the ultimate service of the victims of current urban development models - i.e., the generalized commodification of cities - and their right to the city.

4. As regards the scope of theoretical creation and research in social sciences, there is a long history of interesting works, from the pioneer works of the Chicago School to those provided by such authors as Mike Davis, David Harvey, Isaac Joseph, Richard Sennett, Ulf Hannerz, Jean-François Augoyard, William H. Whyte, Pierre Sansot, Henri Lefebvre and Jane Jacobs. In the Spanish setting, and in all cases with respect to urban themes, I relate to thinkers such as Santiago Alba Rico, Ramón Fernández Durán, 
José Luis Oyón, Horacio Capel, Francesc Muñoz and Pere López Sánchez; and anthropologists such as María Carman, Monica Degen, Teresa Tapada and Nadja Monnet.

With respect to the scope of urban planning and the designing of cities, the truth is that I only know of a few exceptions that refute the unbearable pressure brought by political and business circles on urban planners and architects, upon which, it must be said, their activities depend. It is clear that I only perceive real possibilities of creation and criticism in the field of intellectual work, in addition to political activism. It is naïve to think that there is a policy, program or plan that can be designed and implemented separately from, or in opposition to, the economic and political interests that prevail today. Only discreet, local interventions could be regarded as deviations from that rule.

\section{Jean-Pierre Garnier, Centre National de la Recherche Scientifique} (Paris)

1. Though not always causing open riots, the socio-spatial polarization of the upper classes, corporate headquarters and luxury facilities and services in the city center is a conspicuous phenomenon with negative consequences. Of course, this process is not particular to present-day cities; it has always accompanied capitalist urbanization. But under the so-called metropolitanization policies - in the context of competition between 'global cities' and to the benefit of 'urban elites' and their 'creative' segments - this dynamic has deepened, creating a new kind of 'apartheid' that deprives the popular classes of their 'right to the city' and also a series of ecological impacts and squandering of resources due to the continuous rise in commuting distances.

2. It is obvious that this conflict cannot be solved without a radical change of power relations between the dominant and dominated classes. We already know about the failure of many planning attempts to relieve or end the 'imbalance' - which is, in fact, inequality - between center and periphery, be it through the creation of 'new towns' or with the development and modernization of the system of urban transport. These efforts conceal or, at best, relocate the conflict, but it will not disappear.

3. In the conventional approach, both at the university and in professional practice, urban sociology attempts to assist urban managers regulate the conflicts and contradictions of city life, not to eliminate them. In the face of processes such as the already mentioned socio-spatial polarization, for instance, the standard urban sociologist would analyze the 'dysfunctions' resulting from it - e.g., segregation - and would even propose actions to prevent and neutralize the potential rebellion of those affected, but he/she would hardly dare to identify the structural causes behind the whole dynamic.

4. It is hard to find effective alternatives to these sorts of approaches. Of course, we can still recall some old European urban renewal experiences that put great emphasis on the preservation of the popular classes in the city center, plans that were developed by progressive local governments such as those in the Italian city of Bologna in the early 1970s. Today, it is much easier to find the correct - i.e., political - response in the theoretical interventions of critical sociologists - Neil Brenner, John Bellamy Foster, Bernard Jouve - or radical geographers - David Harvey, Don Mitchell, Neil Smith - even though they are still a minority in their fields. They have shown that socio-spatial polarization is inherent to capitalist urban development, that capitalism shapes and reproduces its relations of domination in and through space. In other words, these authors have helped us understand the spatial expression of uneven and combined development that characterizes capitalism.

\section{Kanishka Goonewardena, University of Toronto}

I wonder how Friedrich Engels would respond to these vital questions. He would surely note the 'housing question,' which capitalism has only intensified at the planetary scale since the publication of The Condition of the Working Class in England in 1844, as the most pressing global urban problem. And he would hasten to add that the solution to this problem, which the bourgeoisie could only move around and never get rid of, still requires nothing short of a revolution. I would agree. It is easy enough to insist on posing the urban question today in the most radical possible terms, so that we may no longer invest undue faith in doomed measures in housing or other urban-social struggles. But what is to be done and who is going to do it? Engels's approach to these questions in Manchester remains instructive. For having discerned the nature of a novel socio-spatial reality (triangulated by capitalism, industrial technology and urbanization) and assessed the prospects of workers within it, he had the good sense in thinking through the new situation to not make an artificial distinction between urban struggle (living conditions) and class struggle (working conditions) en route to socialism. Yet this natural unity of class and urban struggles - which Marx, Engels and later Henri Lefebvre and Guy Debord saw most paradigmatically in the Paris Commune of 1871 - has been largely ignored for much of the last century in the mainstreams of both socialism and urbanism. The organized working class focused on the factory, as experts took over matters pertaining to the city onto their own corporate-professional hands, separating critical urban struggles from radical socialist movements, to the detriment of both.

The overarching failures of architecture and urban planning resulted above all from this excision of revolutionary politics from urbanism, which subtracted the promise of revolution from modernism and left us instead with the will to power of modernization, entrusting both town and country to the logics of capital and state, with predictable consequences for the indignant of the world. The basic lesson from the twentieth century to us should be clear: it is unwise to trust either the market (rigged for the $1 \%$ ) or the state (that refuses to wither away) to deliver the good city and the good life (to the 99\%). Only people organized in ways both radically democratic and politically forceful will make their own history, although now in circumstances ever more heavily mediated by the level of our social reality called the urban. It is the increasing significance of the latter for human well-being, and indeed survival, which makes the slogan The Right to the City potentially revolutionary today by virtue of its capacity to gather diverse urban struggles occurring throughout the world around radical socialist, feminist and anti-colonial imaginaries. The urban revolutions of the 21st century cannot draw their poetry from the past, but only from the future, that is, from the unprecedented concentration and immiseration of Southern proletarians in the Planet of Slums, which Western intellectuals mesmerized by the 'immaterial labor' of the 'creative class' have yet soberly to notice. In learning especially from the South, workers in the urban-spatial disciplines and practices must resist the tendency to domesticate The Right to the City within the liberaldemocratic status quo, abstracting urban space from global social totality. They must instead raise The Right to the City banner, as both Engels and Lefebvre fully intended, only in unison with another: Another World is Possible!

\section{Mark Gottdiener, University at Buffalo}

1. Cities cannot have conflicts. That is a reification that is all too common. I would recast the question by re-conceptualizing urban studies away from privileging the city as the contempo- 
rary form of living and working space. For quite some time, the 10,000-year-old 'city' and the more recent 'city-suburb' dichotomy have been transcended by a new urban form that I call the 'multi-centered metropolitan region'. Requiring a new vocabulary and new analytical categories of de-centralization and re-centralization, commuting, socio-spatial networking, community without propinquity, industrial and commercial location theory, and more, this qualitative change challenges the field of urbanism to recast its ideas as well as its language.

2. Academic turf issues and ego-centric battles retard the necessary multi-disciplinary thinking that would result in a clearer understanding of issues. Certain American Geographers and 'global city' Sociologists, for example, have turned 'Henri Lefebvre,' and 'space' into brands. Addressing new needs and problems created by the multi-centered nature of urban life languishes as a result.

Yet, by far the biggest hurdle is the hegemony of the Late Capitalist system itself. Moribund worker movements siren-songed by consumerism covered by a bank and credit card tab have allowed a restructuring of wealth into the palms of the super-rich on an unprecedented scale. As sign-value and the new symbolic universal of exchange dominate society, economic necessity, the former driving force of the historical subject disappears from consciousness. Rethinking a critical response to economic, political, cultural and social ideologies of domination is required.

3. The present Late Capitalist conjuncture pushed aside most of Academia a while ago except for one-dimensional instrumental fields in the Natural, Informational and Engineering sciences. Gravity's Rainbow knowledge dominates. In the 1970s, the interdisciplinary and international project known as the 'New Urban Sociology' made a distinguished, unique effort to create a critical socio-spatial science addressing the contemporary needs of Urbanism as a unified endeavour. It failed to unite the disciplines in that regard. Yet, I'm still optimistic because my textbook of that same name (Gottdiener \& Hutchinson, 2010) is now in its fourth edition and the critical urban perspective has been fortified by the current economic meltdown of the housing market and totally skewed income distribution, providing new evidence for Engels' 19th century observations that capitalism, in any form, will never solve its dual problems of housing and poverty.

4. Now, for the first time since the 1960s, street protests have captured the transformative imagination. They are as outside Academia as is possible for a change. Occupy Wall Street, or, the early, pre-Islamic reactionary protests of the Arab Spring immediately come to mind as exemplars that hold the promise of confronting hegemonic forces that have been having it all too easy for so long. If anyone bothers to reread Engels, or pays close attention to Lefebvre's comments about him in La Pensée Marxiste et la Ville, they will learn that we do not need more theories or academic conferences now; we need asses out on the pavement and in the public places confronting the spaces of power and their veritable locations in unified political action.

\section{Peter Hall, University College London}

1. The main conflict is the generation of more sustainable urban forms and modes of functioning. Though it has always been a central concern of planners to create better relationships among home, work, services and transport, this has come to the forefront in the last decade, as planners have faced the challenge of global warming. Urban planning is by no means the sole means to achieve more sustainable cities; standards for building and for waste disposal, for example, are equally important. But it plays a central role in the battery of tools.
2. I would mention three possible fields of intervention. First, reduced investment in adapting cities to mass motorization, with concentration on seamless public transport systems with easy interchanges, and better provision for cycling - especially segregated, safe bicycle lanes and bikeways; reallocation of street space to public transport, cycling and walking. Second, promoting compact, mixed-use - but not necessarily high-density - urban forms served by good public transport, including new compact suburbs and satellites. Third, building discrete new settlements, compact in form, served by excellent public transport links to nearby cities.

3. Planning helps to improve our analysis of cities, achieving better understanding of the ways they work, and can be made to work, through close comparative empirical study of particular cases - especially 'best practice' examples of places that already score highly in sustainability terms. Planning's capacity for synthesis is also important: developing the optimal bundle of policies - regulatory, fiscal, physical - to achieve sustainability.

4. There are numerous examples of European (and some other) cities that in the past decade have been widely cited as examples of best practices: Hammarby Sjöstad in Stockholm, a medium-high-density, inner-city area on the site of an old industrial plant, particularly remarkable for its treatment of waste; Västra Hamnen (Western Harbour) in Malmö, a similar redevelopment of a derelict shipyard; Copenhagen, for achieving one of the world's highest levels of bicycle use; the so-called VINEX settlements in the Netherlands, mainly satellite towns and urban extensions to major cities, served by excellent public transport, and Freiburg, the medium-sized south German university city that has emerged as the model of sustainable development on every criterion.

\section{Gita Kewalramani, University of Mumbai}

1. The most pressing conflict of cities in developing countries is the distorted housing market. In India, the total urban housing shortage in 2007 was 24.71 million units, $99.84 \%$ belonging to low income groups. This has resulted in proliferation of slums, which currently account for $1 / 4$ of all urban housing.

The housing market is characterized by several 'contradictions'. In Mumbai, for example, where $60 \%$ of the population live in slums, there are more than 30,000 vacant dwellings. Ironically, the excess supply of housing has been accompanied by a steady rise in prices. This is because the urban housing market is intrinsically linked to high land values. The supply of housing in cities is skewed in favor of the upper and upper-middle income groups, where the profit margins are high. Only $28 \%$ of the total residential properties under construction in the top seven cities in India are valued under US\$69,293. Ironically, $44 \%$ of these apartments are also lying unsold because they are located at the periphery of the cities. In developing countries, upperclass residential areas are mainly located in the city center, while the middle and poorer classes live in the distant suburbs. Commuting to work is expensive and time consuming, and public transport systems are highly overloaded. Therefore, sections from these groups opt to live in slums, which are better located for access to jobs than units in new green-field developments.

2. Land is at the crux of the highly dysfunctional urban real estate market. The main fields for solving this conflict should include: a. Unlocking land supply by removing regulatory constraints and bottlenecks. Removing rigidities at any point in the urban real estate supply chain can improve the availability of low-income housing. Policy instruments such as rent control, coastal zone regulation and other restrictions that have artificially limited the supply of physical land must be repealed or rationalized. 


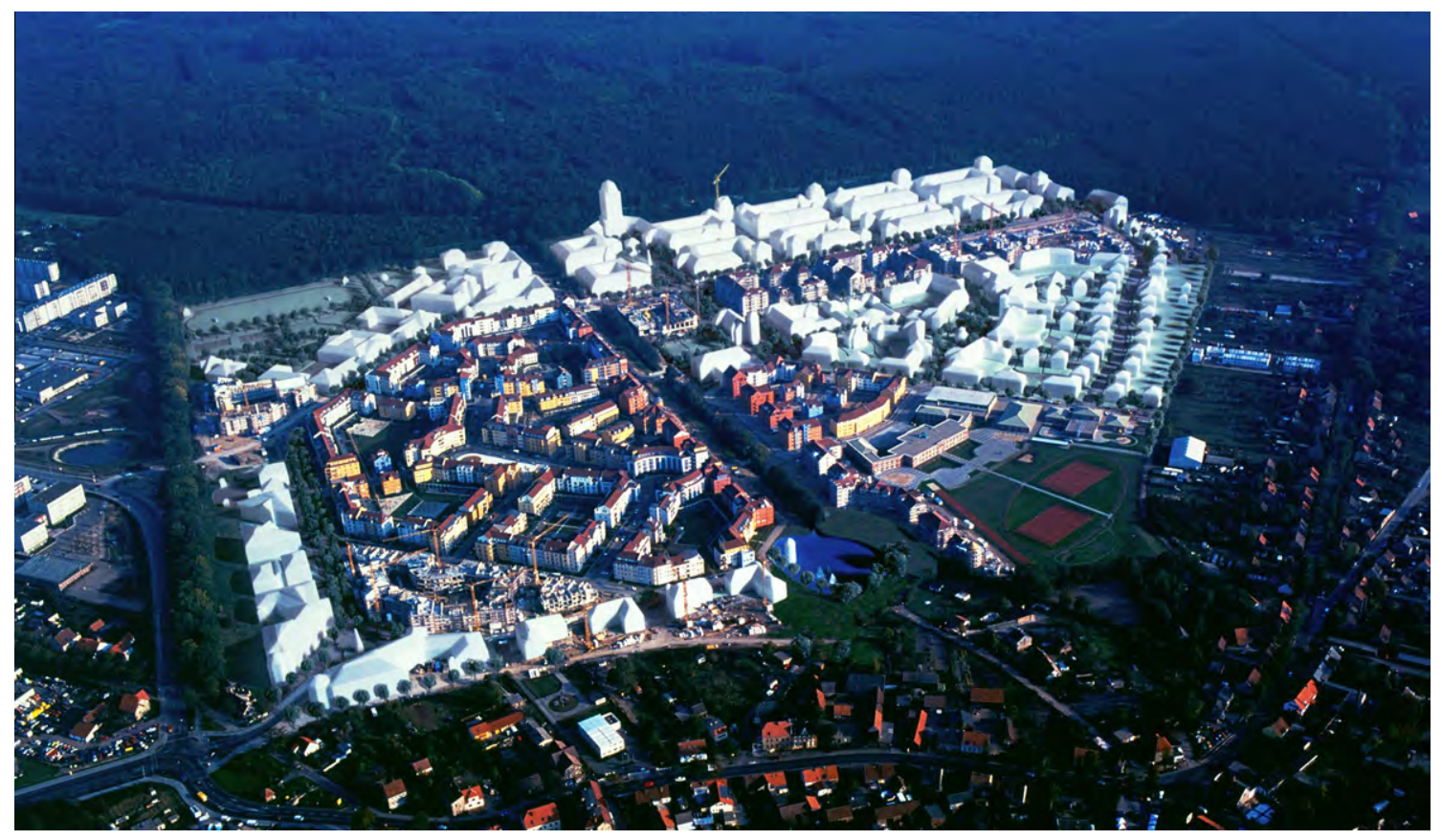

Fig. 1. Kirschteigfeld, Potsdam. KK Gesellschaft von Architekten mbH.

b. Taxing high end development to promote low cost housing must be avoided. Policies of cross subsidizing housing for slum dwellers out of the costs of putting up new housing developments for the non-poor and provision of regulatory relief against provision of homes to low-income groups are popular with governments because they have no visible budgetary costs. However, increases in prices of high end housing have a negative effect on the entire housing supply chain.

c. Massive investment in urban infrastructure. This will permit intensive land use and concentration of population where people want and need to live and alleviate pressure to regulate the supply of built space.

3. Geographers, by emphasizing location and space and studying the spatial processes that create patterns observed in urban areas, have a broad overview of the dynamics of a city and are thus ideally suited to examining the conflicts to which I refer.

4. The Cluster Development approach instituted by the Municipal Corporation of Greater Mumbai in 2009 leverages land use to improve the quality of life, and create infrastructure and housing stock in Mumbai city.

\section{Rob Krier, KK Gesellschaft von Architekten mbH}

1. The art of designing cities has been forgotten - just compare the present situation with that still alive in the late 1930s, all around the world. We must come back to the old fashioned Bebauungsplan, ${ }^{3}$ which fixes the layout of a city according to the bodies and the architectural quality of houses, the network of streets and squares, the location of public buildings. Of course, this does not mean that we have to overlook functional aspects, which must always be considered. But any new planning in the city should be such that it fits into the general order and offers a formal response to existing spatial patterns.

\footnotetext{
${ }^{3}$ With this term the author refers to the traditional planning documents by the first generations of German and Austrian urbanists, which placed great emphasis on urban and architectural design, building volumes and heights, etc. (Editor's note).
}

2. It is a matter of culture! Sincerely, I cannot think of any solution for the desperate situation in urban design worldwide. Just see, for instance, what is being taught in our architecture schools, the conventional practices of town planning offices in our cities, look at the results of urban design competitions. Here in Berlin, think of what has been built during the last 20 years.

3. I can only talk about my own architectural approach, not about architecture in general. And I would like to think that my personal contribution is contained theoretically in the projects for which I have been responsible.

4. I have always tried to apply the principles I have mentioned in my own work, both as a professional urbanist and as an urban and architectural theorist. Among my projects I would highlight those in Germany - Potsdam-Kirchsteigfeld (see Fig. 1) - and, especially, in the Netherlands, the Brandevoort (Helmond, North Brabant; see Figs. 2 and 3) and Broekpolder (close to Haarlem) districts, both VINEX locations. Regarding my theoretical work, I should mention the books Town Spaces. Contemporary Interpretations in Traditional Urbanism (Krier, 2003) and the old On Architecture (Krier, 1982).

Vittorio Magnago Lampugnani, Eidgenössische Technische Hochschule Zürich

1. The urban sprawl. It is the most unacceptable of all existing urban strategies and needs to be replaced by alternative ways of extending our cities. That is, of course, if our cities really need to be extended. My working thesis is: The urban periphery does not exist; there is either city or landscape, and the line between them has to be drawn as sharply as possible.

2. The main fields of action are politics and economics, but obviously these must be tackled by more competent people than we are. As architects, we have the task of developing compatible, sustainable and socially acceptable urban typologies for the densification and extension of our cities; typologies that destroy as little as possible of our natural landscapes and achieve an intelligent balance between architecture and open space, between the private and the public. 


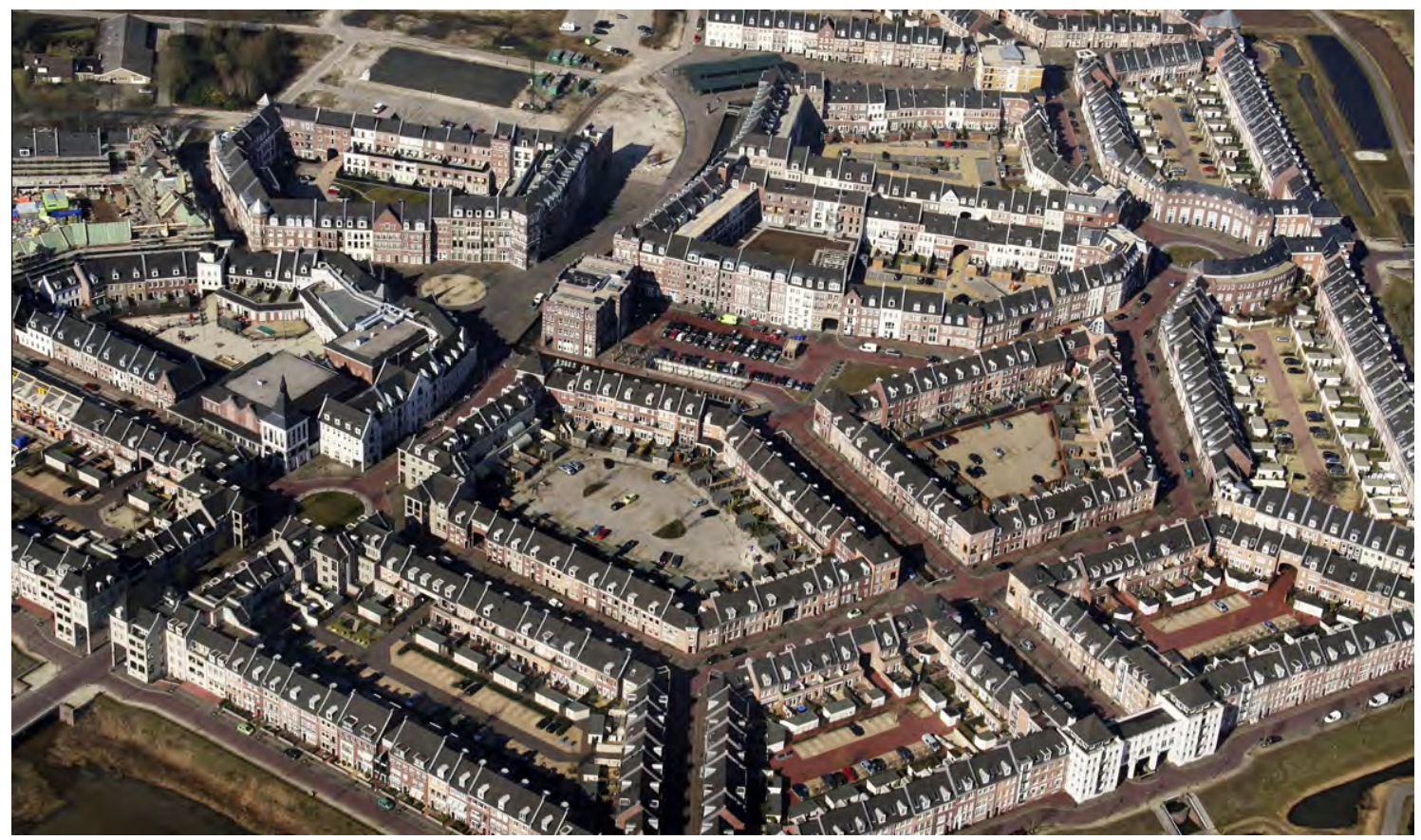

Fig. 2. Brandevoort, Helmond. KK Gesellschaft von Architekten mbH.

3. My discipline, the history of urban architecture, is a kind of memory bank of mostly successful strategies for the development of our cities. It is a recipient of stimulating urban theories, of innovative urban architecture models that have been produced on the basis of those theories and that have proved their value in use, and also of planning tools that have effectively implemented these models. History is never something that can be reproduced or imitated, but it can be searched for answers to current problems. And, of course, it is the best instrument for productive criticism.

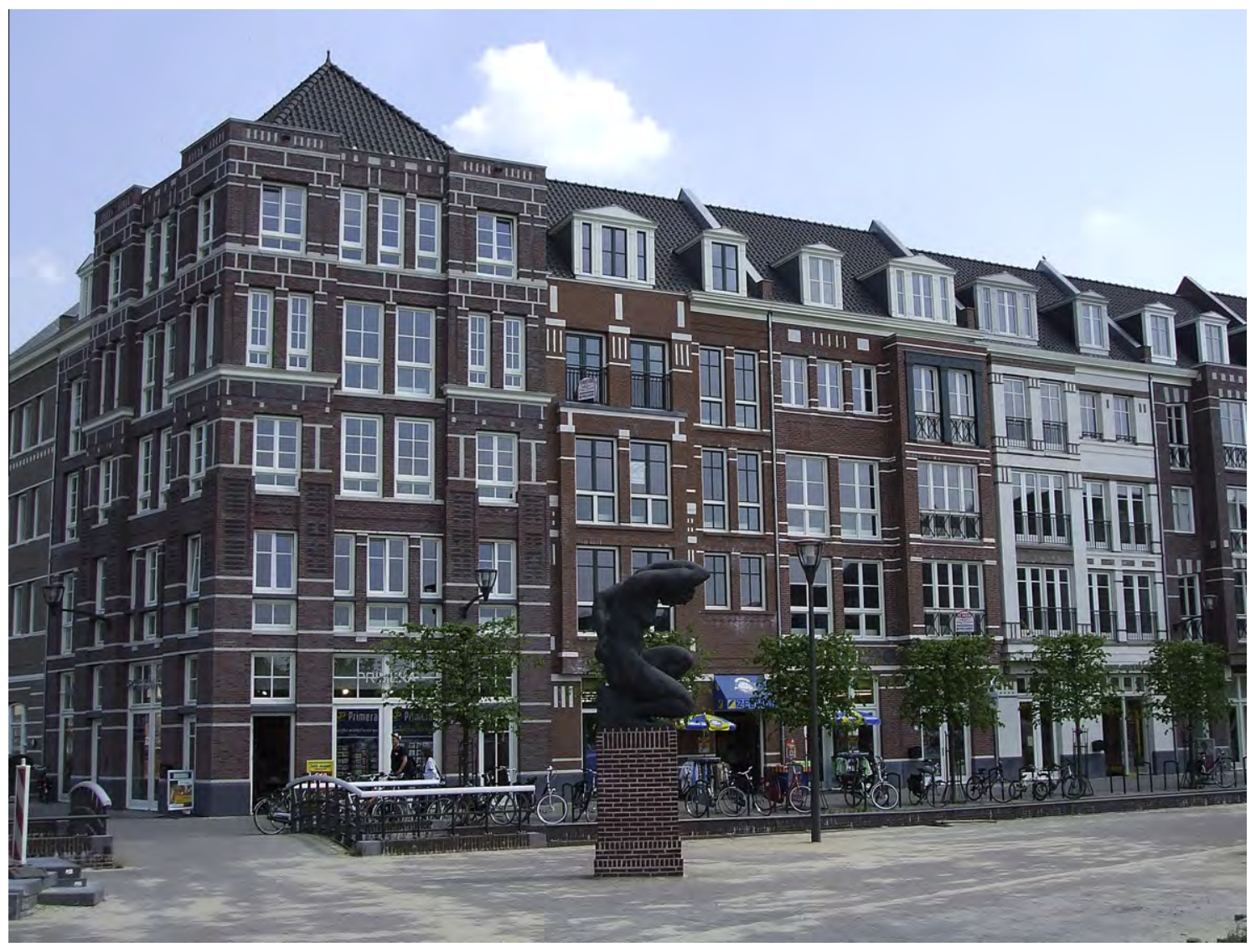

Fig. 3. Brandevoort, Helmond. KK Gesellschaft von Architekten mbH. 


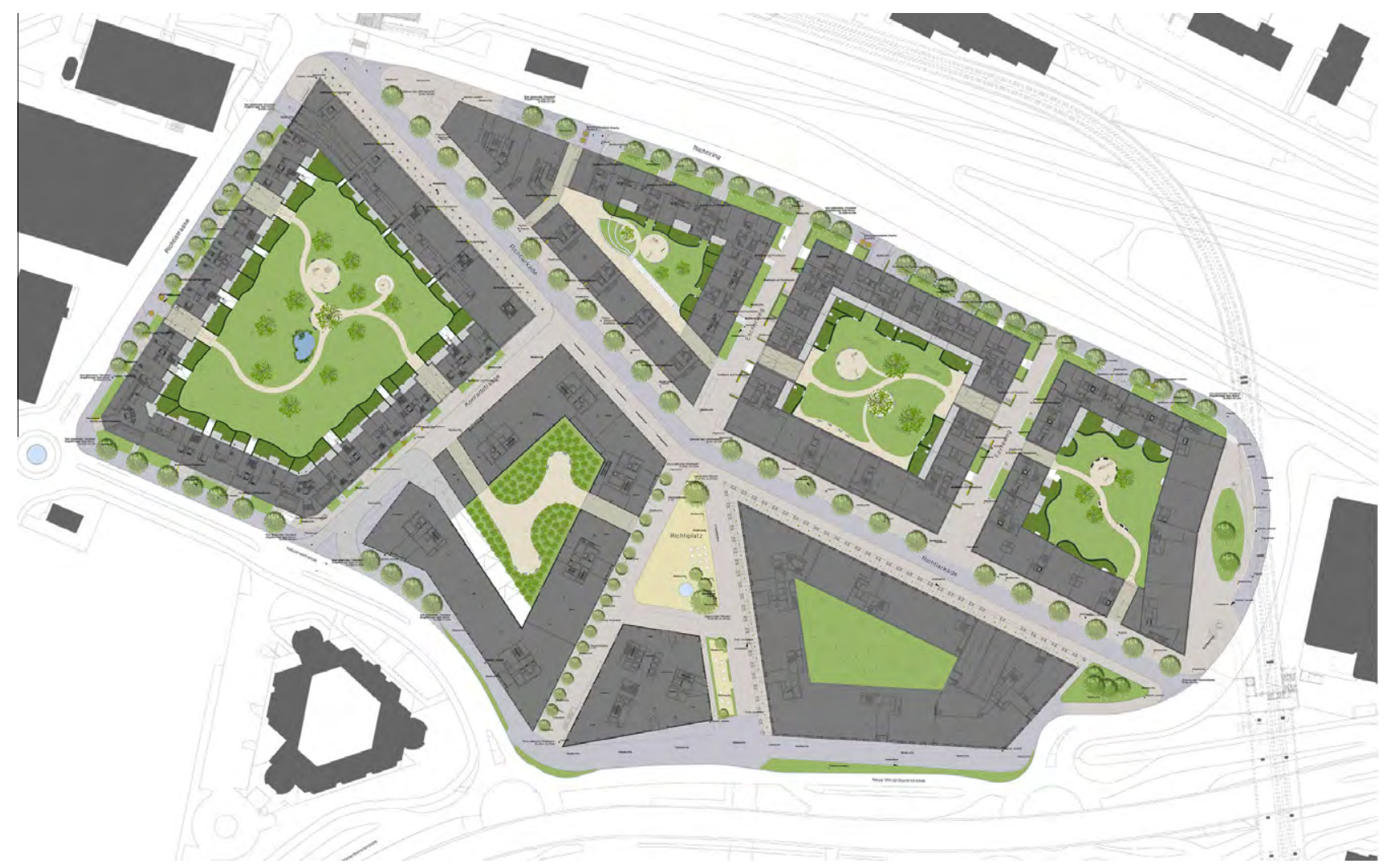

Fig. 4. Richti-Quartier, Wallisellen. Studio di Architettura, Vittorio Magnago Lampugnani.

4. Immodestly, I like to think that my short essay 'Memory and critical science: re-establishing the discipline of urban design' (Magnago Lampugnani, n.d.) indicates a possible way out of the dilemma of contemporary urban design, inviting the new urban architects to present themselves not only as designers and creators, but also as researchers and scientists. In fact, I believe that urban development is less a matter of a stroke of genius than one of patiently building the foundations that partly already exist and partly have to be created. In the field of concrete urban work, I hope, again with immodesty, that projects stemming from my office, such as the Richti Quartier near Zurich, demonstrate a possibility (not the only one, of course, but one) of extending the city without contributing to its disintegration (see Fig. 4).

\section{Luigi Mazza, Politecnico di Milano}

1. Despite the difficult economic and social situation, Italian cities do not face a large number of conflicts. There are, of course some particular cases, such as the bitter debate about highspeed rail in Val di Susa - a special case of bad projects and governance - or the conflicts in Naples - a problem of politics and crime. Yet, more generally, the conflicts are within neighborhoods and are often related to racial issues. It is possible to explain this lack of confrontation if we consider that the trade unions are weak and the left-wing parties are divided and uncertain. The dreams that right-wing politicians promised and an acceptable quality of life that existed until a few years ago have produced a general numbness. But those dreams have now faded and, after a long period of relative calm, Italy may face a new era of disorder and conflicts. The new government's policies and budget cuts have had a huge impact on the population. It is difficult to foresee what will happen in the future.
2. The key field of action in Italy is certainly the political one - but our institutions are weak, self-centered and unable to consider, understand and solve the main difficulties of everyday life.

3. Planning is effective in small cities, but perhaps it is inoperative in large ones. In small towns, social control, participation and a conservationist approach - either from the left or the right can make spatial planning useful. But if we face unemployment or other forms of economic crisis, traditional planning tools are not very helpful - though, of course, they can pave the way for the implementation of responsible policies. Let me provide an example. A small Italian city launched a plan for the renewal of its historic center, where about 3,000 families were living in unhealthy conditions. The real estate lobby strongly pressed to use the plan as an opportunity for investment. On the contrary, the planners' suggestion was to do almost nothing. When the local stakeholders asked them to justify this decision, the planners reminded them that, despite the difficult social situation of most Italian cities at that time, this particular town had been lucky and avoided strikes and public disorder. The question was: 'Would you provoke these conflicts now, implementing a housing policy of eviction and producing the subsequent social crisis?' The audience understood. The industrial lobby was more important than real estate companies, so the local government accepted the proposal and two plans were prepared: a detailed plan for the preservation of buildings, services and facilities in the historic center, and a second plan for a new suburban, popular, neighborhood where workers could gradually find an alternative to their unhealthy homes.

So, while it is possible to accept the effectiveness of planning in this kind of small context, it is difficult to believe that we can apply comprehensive schemes in larger cities. In these cases perhaps only specific policies are operative - the reasons are both political and technical. 
4. I have tried to address this challenge in a chapter of the collective book Milano al futuro. Riforma o crisi del governo urbano (Future Milan. Reform or Crisis of Urban Government) (Mazza, 2011). There, I study the effectiveness of different planning tools both in small and large cities, providing a general account of planning systems.

\section{Alberto Mioni, Politecnico di Milano}

1. For some time, the transformations in the settlement system in Italy have not been the result of an organized 'development' but of uncontrolled 'mutation'. From my standpoint, the effect of this mutation is the collapsing of the foundations of the 'search for public utility,' which supported the urban planning machinery until the end of the 1990s. Today, urban planning is officially dead and has given way to other practices - just as seductive as they are evanescent and hardly verified - which, in my opinion, have proved to be extremely disappointing to date. Thus, the changing spatial dynamics of our cities are regulated by democratic institutions that, though competent, employ mechanisms that, even when brilliant or pre-meditated, are not of a binding nature. The decisions regarding the solutions for settlements on diverse scales are taken by private entities, often in an inappropriate and imprudent manner.

The results of the current method of controlling the territorial transformations under way in Italy appear to be depressing and unfair, and this is not only my opinion; the impotent, chaotic, disastrous country we are creating is there for all to see. However, in this absolutely negative scheme of general changes, our cities - and many other pathologies due to the multiplication of all types of new and old structural problems - continue to be affected by two serious conflicts. First, the conflict existing between the interests of public utility and the search for profit from real estate regarding the use of land, tackled time and again in the most contradictory fashion, but never solved in theory or in conventional practice; second, the conflict that exists, at least in Italy, between the 'discourse' and 'practice' of both interests, with a vast distance between the declarations of intent and the facts that follow them.

2./3./4. If these conflicts refer to a kind of inalterable genetic heritage of Italian urban planning, there is very little to be done, at least with the disciplinary instruments at our disposal. However, I do not think this is the case. On the contrary, I believe that the issues I have raised must be reconsidered from a new perspective. In particular, planning must carry out the following urgent tasks:

(a) A conceptual, ideological and operative reformulation of the idea of 'searching for public utility'.

(b) A clear, conceptual, ideological and operative definition of the criteria to be assumed as a basis for evaluating - in terms of functional and formal performance - the project solutions proposed by public and private agents that are intended to change the physical arrangement of sites, in order to make a rational comparison of the different hypothetical options and their feasibility and for monitoring the interventions that are put in motion.

For many years, accredited public and private research institutes have worked on these arguments, in conjunction with universities. ${ }^{4}$ Optimum results were obtained, which, nonetheless, were ignored by the political system of that time. Even today, it would be possible to plan and develop scientific research of a similar nature. But putting the results into practice, both now as in the past, is the task of legislators. I personally do not feel very optimistic in this respect, but the challenge may well be worth it.

\footnotetext{
${ }^{4}$ In particular, I would like to mention the texts published between 1990 and 1992 by the Istituto Regionale di Ricerca della Regione Lombardia.
}

\section{Alain Musset, École des Hautes Études en Sciences Sociales (Paris)}

1. There are so many real or imaginary conflicts in contemporary cities that I find it quite difficult to say which one I think is the most important in understanding the current processes of decomposition in urban societies. However, I would like to say that such processes are not the result of existing dubious metropolitanization processes, which are often presented as a general framework for explaining the alleged chronic diseases of modern and post-modern cities. In actual fact, the sources of the conflicts between diverse social classes and types of communities have been configured, in the longer term, within the socio-spatial and political organization of capitalist cities.

Personally, I must say that my approach to critical geography in analyzing this type of problem is quite recent, and I still have many stages to pass through. My initial research was focused on historical geographies aimed at studying the conflictive relations between city, society and environment, above all in Latin America. I changed my course at the start of the 21 st century, when I began to undertake more specific research into social inequalities and spatial justice in indigenous areas of Nicaragua. On seeing that more 'vulnerable' social groups accept and put up with appalling living conditions, we should call into question the notion of 'resilience'. Indeed, as I see it, the most important conflict in contemporary cities is acceptance by the least favored segments of a system that maintains them outside the margins of society and the city in economic, cultural, political and spatial terms.

2. Within the heart of the neoliberal capitalist system, there are no solutions, only illusions. As is well known, the city, as with any other type of territory, is not just the reflection, but also the material expression of, an ideology. Trying to fight, mitigate or elude social inequalities, expressed in the unequal organization of space (for instance, through public policies for access to housing, improving transport systems, or rehabilitating the habitat of the poor) is merely a dissuasive deterrent.

In this respect, the famous 'right to the city' of Henri Lefebvre has led many researchers to 'fetishize' the object 'city'. On the contrary, we should first think of society and then of the territorial forms that are not the cause of its organization, but the consequence. For that reason, one never speaks of the 'right to the countryside' or the 'right to the village,' as if the conflicts existing in cities did not also exist in the rural world.

3. I think that it is no longer possible to think in terms of closed disciplines when analyzing the processes that affect contemporary cities. In France, social geography has a lot to do with sociology and we usually base our research on the works of sociologists and anthropologists.

4. Apart from the works of Lefebvre, three theoretical events have oriented my current work on the city: historically, the book by Engels on the situation of the working class in England, with its anthropological descriptions of the habitat of the workers employed in the factories in Manchester; in the field of critical geography, the classic works of David Harvey, and, of course, in France and with regard to the critical study of capitalist cities from a sociological perspective, Jean-Pierre Garnier's work, from Des barbares dans la cité (Garnier, 1996) to Une violence éminemment contemporaine (Garnier, 2010).

\section{Zaida Muxí, Universitat Politècnica de Catalunya}

1. The most pressing problem of contemporary cities is their strong 'dualism,' which is no longer exclusive to developing countries, but also occurs in Europe and the USA due to the neoliberal policies applied since the 1980s. As a consequence, the 
gap between social classes has increased. In this context of inequality, women are the ones who suffer most - it is more difficult for them to access essential resources, though they are crucial active agents for the well-being of the whole city and its population. Therefore, it is essential to work to make their experiences visible and to respond to women's needs, considering sexual and gender categories.

2. The main fields of action are the democratization of urban planning and the abandonment of speculative practices in order to address inclusive planning. The channels to direct these efforts are the real participation of citizens, as well as the work on women's empowerment as active agents of transformation.

3. Architects' approach to urban planning takes into account aspects and knowledge related with life experiences of people inhabiting the spaces we work with. The experiences with groups of women analyzing urban spaces and proposing solutions or improvements for the everyday life has taught us that their knowledge is essential, even though the dominant practice of planning has historically overlooked it.

4. I would mention the Catalan Law for the Improvement of Neighborhoods, Urban Areas and Villages Requiring Special Attention. Its main goal is to help neighborhoods with population at risk of exclusion in order to avoid urban segregation and segmentation. The law was designed as a process of cooperation and participation between different administrations and departments. This allowed interrelated actions from different areas - social, urban, environmental and equality issues were addressed together and not in an isolated way, as is usual. The eight fields of intervention were (a) improvement of public space and creation of green areas; (b) restoration and placement of collective elements in buildings; (c) provision of public facilities; (d) inclusion of new information technologies in buildings; (e) promotion of sustainable urban development; (f) gender equity in the access and use of spaces and public facilities; ( $g$ ) development of programs to improve social, economic, and planning conditions in neighborhoods; and (h) accessibility and elimination of architectural barriers.

Also, this law has been a leading tool to foster urban planning with a gender perspective. Point 6 of the Law addresses the promotion of equal opportunities in the use of public facilities and public spaces through urban renewal. A gender mainstreaming approach is an essential tool for working within a gender agenda because it entails (among other aspects) women not being considered a minority or a problem but an essential constituent group of society. In consequence, it is necessary to re-direct current systems of thought and behavior, which are based on abstract neutrality that exclusively corresponds to male experiences and mentality.

\section{Michael Pacione, University of Strathclyde}

1. This is an impossible question to answer given the variety of urban environments that characterize our contemporary urban world. However, in view of my experience of cities across the globe and personal research, I would contend that inequalities in standards of living must represent one of, if not the key, challenges confronting modern cities. My own research over 30 years has focused on mapping socio-spatial variations in urban quality of life, concentrating particular attention on conditions at the disadvantaged end of the quality of life spectrum, in developing a critique of current urban policy and planning, and in demonstrating the potential of a geographical perspective in addressing the multi-dimensional social, economic, cultural and environmental problems of cities.
2. The socio-spatial disadvantages that characterize large urban populations are caused by a plethora of factors operating at a variety of spatial scales, from global to local. It follows that any attempted solutions must also be multi-dimensional in scope. These include action on a global scale to reduce inequalities between countries, at the national scale to reduce variations in opportunity and wellbeing between regions, and at the urban scale to overcome disparities in quality of life between communities. Such ameliorative action will require coordinated, concerted efforts by public sector and private sector agencies, action that may not be forthcoming due to the differing priorities of interest groups in capitalist society. The fact is that the poor will always be with us - all that can be done is to seek to lessen the gap between the haves and the have-nots.

3. Geography and, in particular, my own field of urban geography can play a fundamental role in analyzing the problems of sociospatial variations in wellbeing. Geography is a quintessentially synthesizing discipline that incorporates relevant theory and methodology from a variety of social sciences to illuminate the causes and consequences of urban problems. The geographical perspective I have employed also provides a particular approach that disentangles the complexity of the problems of urban disadvantage by using the concept of scale of analysis to disaggregate the issue into its component elements, thereby simplifying the identification of both problem and possible response. The geographical approach, therefore, provides a unique view of the challenge of urban socio-spatial disadvantage.

4. One example of my own work that exemplifies the geographical approach to which I refer is published in Michael Pacione (2003).

\section{Nuno Portas, Universidade do Porto}

1. The contemporary city has come as a surprise to urban planning traditions and, through the acceleration of socio-economic and technological changes, has also had an impact on the forecasts of planning - and not only spatial - instruments, particularly those characterized by a juridical and/or architectural lack of flexibility. The most serious conflict lies in the contradictions between mobility - in terms of people, commodities and capitals (limits/densities of the inherited and planned urban fabric) - and the environment. A particularly outstanding phenomenon consisting of what I would call the 'developing sprawl-city': conurbations, Zwischenstädte, rururban areas, etc. This lack of capacity to react requires us to reconsider new problems and old solutions; some of them, rejected by the Modern Movement, have been recovered thanks to their capacity to adapt to the present uncertainties.

2. The greatest urban conflict lies in the inequalities that have built up during the past century between 'cities-with-history' - with dense, constant growth - and 'other-cities,' which undergo random, more or less diffuse growth, including situations of illegal or rururban settlements. Re-qualification and equality in accessing the services of other areas of new growth - especially in countries or regions with low GNPs, including European areas - require an urgent reconsideration of our reurbanization strategies through research and development, a review of housing types, the introduction of efficient improvements regarding sustainability and the environment, and also in the forms of empowerment and governance. Our 'Architecture and Urban Studies Planning Center' in Porto University has dedicated more than 20 years to applied research into these subjects, which are of primordial importance for Portugal.

3. Extensive urban planning, which is more or less dualistic in its forms - historic and post-historic - cannot be reduced merely to the physical structures handled by architects, civil engineers, 
lawyers and economists working in the construction field. Territorial re-balance always depends on the administration and re-distribution of the available material and human resources and, ultimately, on an appropriate political structure for the existing complexity in urban agglomerations. Even in more developed countries, reforms are necessary to enable the management of the 'transversal' skills imposed on urban units with greater complexity (and inequalities) because the sum of the townships cannot ensure the progressive equity of the whole - i.e., prevent splintering tendencies.

4. Relevant urban conflicts - inequalities in resources and environmental conditions - have led me to reconsider the urban project' in Mediterranean and Latin American settings. The alternative to this is planning with uncertainty (i.e., with the time factor), with the potential empowerment of the recipients and the limitations of endogenous and/or public resources. Similarly, it is necessary to give priority to the 'layouts' of collective space - mobility and durable landscapes - leaving room for the future development of different types and lifestyles and contributing to reflexive, proactive, continuous (i.e., intelligent) urban development.

\section{Ivor Samuels, University of Birmingham}

1. Today's urban environment is the result of 30 years of neoliberal policies. Urban space in the UK reflects a society with growing inequalities. These have been exacerbated with the austerity policies being imposed with the excuse of the recent financial difficulties of the Western world. Inequalities are manifest both within and between cities. Thus, there is a growing segregation of different class and income groups within all cities in the UK. Because of changes to the way housing benefits are paid, it has been estimated that 82,000 poorer families will be obliged to leave rented homes in inner London and move to outer boroughs where housing is cheaper.

Within the cities, we have seen the growth of housing in 'gated communities,' where those with financial means seek to protect themselves from what they regard as an underprivileged and hostile populace - the proletariat. The August 2011 riots, which so shocked this country, affirm the correctness of this diagnosis. In business districts, space is increasingly being removed from the public realm. For example, recent office developments in London, while visually apparently part of the public realm, are in fact private so that 'undesirable' individuals can be removed by private security guards, and even architects taking photographs can have their cameras confiscated. At the regional scale, the cuts in public services will hit hardest those parts of the country that depend most on public aid and support, i.e., the regions that were the home of the industrial revolution and where heavy industry has experienced a long decline.

Deregulation in the field of housing has led to abolition of minimum space standards in private housing. Even public rented housing presents now a higher quality. For example, in some private house types there is not enough room for the whole family living in a four bedroom house to sit down for a meal together.

2. A book by journalist Anna Minton, Ground Control (Minton, 2009), admirably sets out the problems described above. This book is in the tradition of non-professionals questioning professional activity and follows the example of Jane Jacobs' seminal work.

3. It is difficult to imagine a real and broad possibility to contribute from the fields of architecture and planning. Architects depend on developers for their work, and planners' attempts to regulate development are hampered by the lack of staff and a reluctance to refuse projects for fear of the applicant appealing against their decision with the council having to pay legal costs. There is also a lack of skills in planning departments and a near monopoly of a few very large house builders.

4. A scheme called Building for Life (BfL) was initially promoted nearly 10 years ago in order to raise the standard of housing. It is a simple 20 point scoring system for housing quality and while it has many defects, it enabled comparisons to be made, with often depressing results. There are other minor achievements. For instance, some urban expansions have demonstrated how different neighborhoods and housing types can be integrated with sustainable drainage (SUDS) solutions to provide more sustainable developments. Upton on the edge of Northampton is perhaps the most notable example.

\section{Saskia Sassen, Columbia University}

1. The question of excessive inequality. Having extremes of wealth and poverty alters the urbanity itself of the city, especially if it entails an impoverishment of the middle and working classes. The best for a city is a vast modest middle and working class: they depend on the city - that is where they make their livelihood and where they can acquire all they need. And because they spend most of their money in the city, the city's economy can thrive, including neighborhood economies. An extremely wealthy and global $20 \%$ of its population can mean mansions built out of several housing plots, and absentee owners. This actually deurbanizes a city. A city is about mixing, rubbing shoulders, a thin sociality that makes that mixity easy, where no stepping on another's foot or having body contact is taken personally - as it would in the neighborhood. The best for a city is an economy with fairly distributed benefits (the opposite of what we see today in global cities).

2. One key strategy that I find in my research is that serious programs and efforts to green a city will produce distributed outcomes. This is not a single, isolated program, but an assemblage of programs and interventions. And it will take more than the standard mitigation and adaptation. It will take a far more radical approach, working with the biosphere rather than simply reducing our damage. I have written about how a serious effort to make cities environmentally sustainable and active innovators would actually cut across differences of class, ethnicity, and religion. And it would create jobs. I think this would require going beyond policy and beyond carbon-trading. It would require actively using the biosphere's capabilities where we now use chemicals, etc. made in factories.

3. We have some of the elements, but we need to break out of analytic cages that are keeping us from seeing a broader landscape for action. Examples of this breaking out of the established cages are my work on global cities and my current work on delegating back to the biosphere (see Sassen \& Dotan, 2011).

4. For instance, biologists have found that a particular bacteria, when put in dirty organic waters, as in our bathrooms and kitchens, actually generates a molecule of a kind of plastic durable, resistant and biodegradable. Because we need vast amounts of plastics, and currently use non-biodegradable plastics that are highly destructive of the biosphere, we would have recoded what is now a negative for cities - how to get rid of all that waste - into an input for making a basic ingredient. Cities would actually export some of their dirty waters to places where there is not enough! Now that is a serious recoding.

\section{Jianfa Shen, The Chinese University of Hong Kong}

1. In China, the biggest conflict is the lack of affordable homes in growing cities. GDP per capita has increased significantly in the recent decades, and many rural migrants have moved into 
Chinese cities. The share of the urban population in the total population passed the 50\% mark in 2011. However, housing prices in Chinese cities have risen much faster than the income of urban residents. Many new flats have been built, but they are not affordable to ordinary urban residents and migrants.

2. There are several ways to end this problem: increasing the wages of low-income citizens, regulating the housing market, ensuring land supply and provision of subsidized housing, etc. Of course, the government should take a leading role in regulating the land and housing markets. For example, the government can collect property taxes to increase the cost of owning large or extra housing units. The government can use the property tax revenue to provide subsidies to low-income households or to build subsidized housing.

3. Urban geography can provide a systematic knowledge of the growth of urban populations, income inequalities, the demand and supply of land and housing, and so contribute key and useful material for policy-making. Comprehensive surveys of land resources and housing conditions are particularly useful to provide complete information on the demand and supply of land and housing, reducing speculation in the housing market and the risk of a real estate bubble.

4. The Hong Kong public housing program: it plays a very important role in the provision of houses for low-income populations.

\section{Michael Sorkin, The City University of New York}

The contemporary city is afflicted by estrangement. We are estranged from each other by ossifying systems of class that continue historic patterns of spatial segregation and privilege; from nature by toxic pollution and the unsustainable practices that dominate the age; and from urbanity by cities that have grown too large, too inaccessible, too uniform, and too harsh.

So many ways to approach these problems, so little time! The pent-up demand for sustainable, equitable and beautiful cities makes itself known in every register. I'm sure I will not be the only respondent to bring up the amazing events of the Arab Spring, the South European indignant, Occupy Wall Street and other mass appropriations - and utilizations - of urban space in 2011. The necessary meaning of such insistent physical assembly is to affirm the relevance of the places that support it and to set an agenda for design action and participation. Cities are crucial to our rights, including the right to invent the city of our desires.

Cities are engines for both concentration and distribution and they must support and encourage differences known, imagined, and yet to be. They must carefully engineer the systems of luxurious austerity that will allow them to rise in defense of the welfare of the planet and all its inhabitants. They must offer hospitality to the architectures of both collaboration and exception. And they must be the memory banks and goads for a shared and sustainable future for all. Work towards this objective can and must take place at every available scale: on the drawing board, in the streets, the schools, and the mind.

\section{Max Welch Guerra, Bauhaus Universität Weimar}

1. If we make a comparison based on the geographic extension and structural nature of current day problems, combined with the scant attention that they receive, the issue of cities and regions with negative demographic growth that also suffer from economic stagnation or recession represents the most significant conflict for contemporary cities in Europe. This problem affects not only anachronistic industrial centers and cities that have lost their administrative functions, but entire regions as well. Europe is losing cohesion.
This constellation of shrinking areas produces economic, functional and cultural complications that recall the metaphor of the vicious cycle, and even more so under neoliberal conditions. An ulterior complication emerges as a result of a weak response capacity and the reorientation of the remaining society. The absence of excess material and lack of expectations make the search for incentives in order to come to a consensus on development alternatives quite difficult. Typically, public administration, business leaders and professionals try to ignore the conflict. To recognize it would imply recognizing the need for a restructuring of the model. The interest groups react by reaffirming support for exactly the same policies that led to the current situation. Those most affected by the process are lowincome groups.

2. The first step is to become aware of the shrinking in all of its various dimensions, mechanisms and implications, distinguishing between the specific phenomenological contexts by country and differing types of cities and regions. Another field of action is reactive adaptation by the territory and administrative structures to the new constellation. A third field is the formation of, and experimentation with, new development models, valuating the contribution of 'goods' that are difficult to quantify, such as environmental and cultural goods, thus further demystifying the hegemonic paradigm of economic growth. None of this is really that revolutionary in Europe, but it is only recently in the making. Internationalizing this information and debate is of the utmost urgency.

3. It is essential to uncouple the concepts of progress and the common good from the hegemonic concept of economic and urban growth. In Germany, there are different projects both within and outside the spheres of urbanism and spatial planning. Another strategy is to tendentiously demonetize and regionalize local life, in order to diminish overall vulnerability to economic storms, reduce ecological costs of consumption, and increase the capacity of the population for self-determination. Examples such as the Italian movement of Cittá slow (Slow Cities) are inspirational. A new and practicable definition for quality of life or social progress cannot be imposed vertically from above, either from the state or experts. On the other hand, the experience of Germany shows that spatial policies and suitable professionals are at the same time absolutely fundamental.

4. Over the past decade, Germany has accumulated experience with a program for the mass demolition of housing and different federal programs for stimulating densification and urban center renewal over suburbanization. Stadtumbau Ost covers almost the entirety of Germany's eastern cities, but barely surpasses the horizon of the housing market. Since 2001, over 260,000 houses (rentals) have been demolished, and by 2016 there could be an additional four million, but only recently have urban and regional planning regimes been learning to organize public services under the conditions of generalized shrinking. It has been necessary to take notice that having a lower population does not lower the costs of technical and social infrastructure - in fact, it increases these costs. In addition, we know that conscious de-growth programs can increase social asymmetry. The German recipes have also been quite useless in Poland, where demographic decline and economic crises have very differentiated spatial implications, as well as in Taranto (in southern Italy), where the problem is made even worse by an abominable level of industrial pollution and chronic incapacity for management. It is, thus, not enough to internationalize research; we must expand upon spatial, descriptive foci with analysis of the economic, social and political dimensions of the day. 
Sharon Zukin, The City University of New York

1. The most pressing conflict in cities today is finding a place to live and making a permanent home there against the continual pressures for mobility, higher property values, and aesthetic upgrades. In some cities this conflict pits residents against a public policy goal of 'urban renewal'; in others, against a market-based trend of 'gentrification'. In terms of appearances, the problem is 'upscaling' the city. Upscaling makes housing of any kind too expensive for most men and women to afford. But the problem in old-fashioned, political-economic terms is who controls the land. Most often the rhetoric of public officials states that they are pursuing the goal of growth, but in reality the elites who control urban land, whether they are elected or non-elected officials, property developers, or large landowners, are trying to create a city that allows them the most freedom to capitalize on their own interests. In cities of the Global North, elites claim to be motivated by competition with other cities. In cities of the Global South, this sense of competition is forced upon elites and reinforces social class, ethnic, political and religious rivalries. The end result is that many people are unable to make a permanent home in the city.

2. I am a great believer in the power of the state to protect social welfare. Only laws can protect the right to land, to housing, and to work in the city. Citizens' rights such as voting and protest demonstrations should be mobilized to create laws that distribute housing fairly and equitably, that control rents, that devise rules to limit uses of space and sizes of buildings (zoning laws), and make it possible for all men and women to become citizens with political and social rights.

3. Sociologists are good data collectors, but we need to become better story tellers. Despite claims of rational thinking, people are not convinced by numbers. They are convinced by stories. They are mobilized by feelings of empathy as well as by self-interest. To engage - or even to create - a broader public, we must tell stories that document the breadth of collective suffering and the depth of individual experiences. Perhaps if we did not think of ourselves as social scientists but as creative non-fiction writers, we would do a better job. I wonder if my friends and colleagues who write about a 'just city' are only heard by those who already are their political allies. Do people who never worry about the social welfare of others pay attention? What about the right to the city'? This is a great rallying cry for those who have read Henri Lefebvre, but for many others (and even for advocates), it may be confusing.

4. In some cities of the Global North, such as New York, where I live, rent controls are a historical policy instrument for making affordable housing and for providing a lifelong right to a home. To me this is the basic 'right to the city'. Unfortunately, the public and even more so, politicians, suffer from an ideological fatigue with rent control. Whether you call it neoliberalism or market fundamentalism, voters and legislators oppose laws that weaken the 'discipline' imposed by markets. How can we get their attention, or even better, their support?

To try to attract the attention of a broader public, I choose to make a cultural rather than an explicitly political argument. I speak about the 'authentic' city, a city of rich and poor districts, which is enriched by cultural diversity and impoverished by social homogeneity. To preserve the cultural distinctiveness of cities - the deep experiences of difference and strangeness that make us feel most culturally creative - we need social diversity. How do we preserve social diversity? By making it possible for everyone to make a permanent home, by making displacement of residents impossible, by strengthening rights to housing and land at low prices. In this way we will preserve the authenticity of our own time and, I hope, the authentic city of the future.

\section{Putting it all together: provisional conclusions and further developments}

A series of conclusions were obtained from all the responses, opinions and topics covered, which we can briefly summarize on a provisional basis. 'Social inequality' and its consequences, in diverse forms and including a multitude of different stances and attitudes, emerged as the conflict most often mentioned in the interventions (contributions by Mike Davis, Jean-Pierre Garnier, Kanishka Goonewardena, Alain Musset, Zaida Muxí, Michael Pacione, Ivor Samuels, Saskia Sassen, Michael Sorkin). This is, of course, a major issue of concern in past and current research (just to mention a few salient recent contributions, see Brenner, Marcuse, \& Mayer, 2011; Fainstein, 2010; Marcuse, 2009; Mitchell, 2003; Soja, 2010), which here appears condensed in its essence and, in some responses, articulated with other socio-spatial contradictions and possible solutions. The other frequent concerns ranged from global warming and the exhaustion of natural resources (see contributions by Adrian Atkinson, Peter Hall), to the impact of new economic forms on the city and the maladjustments that they cause (Pedro Bannen, Bob Beauregard, Simin Davoudi, Mark Gottdiener, Luigi Mazza), from all manner of social revolts and antagonisms (Davis, Goonewardena, Garnier), to the dynamics of commodification of public space (Manuel Delgado, Samuels), gentrification and other attacks on socio-spatial justice (Garnier, Musset, Sharon Zukin), gender conflicts (Muxí), lack of affordable housing (Gita Kewalramani, Jianfa Shen, Zukin), the inefficiency and limitations in our models of urban development (Rob Krier, Vittorio Magnago Lampugnani, Nuno Portas, Max Welch Guerra), deregulation of the urbanization process (Samuels, Alberto Mioni), the eclipse of identity in everyday life spaces (Bannen), rampant global unemployment (Davis), and the ever-increasing pressure on the simple project of finding a place to live and making a permanent home (Zukin).

However, a series of diverging postures was also detected. For instance, it is interesting to note that the two scholars from Asian institutions (Jianfa Shen and Gita Kewalramani), representing the most important emerging economies in the region, China and India, coincided in pointing to the shortage of affordable housing as the greater conflict within their contexts - a problem which is, of course, not limited to these countries (see Zukin's response), though it presents extreme and complex forms there (Logan, 2008; Patel, 2010). Let it suffice to read the solutions that they both propose for resolving this conflict, which are diametrically opposed in their allusions to the need for strong public regulation of the property market and the radical liberalization of land development, respectively. In addition, the contributions of Bannen, Mazza, Mioni, Samuels and Welch Guerra are effective thermometers for analyzing the topics proposed in their respective national contexts (Chile, Italy, UK and Germany).

Sustainability - another major issue in the urban agenda during the last few decades (see, e.g., Atkinson, 1996; Breheny, 1992; Girardet, 1992; Heynen, Kaika, \& Swyngedouw, 2006) - appears as an explicit or implicit principle in many responses. However, it is presented in different forms, ranging from the more classic (Hall) to other more speculative (Sassen) or radical (Atkinson) approaches; from those who assume it directly as a general principle (Sorkin) to others that merge tangentially with it (the perspective of complexity and interpretive planning in the case of Davoudi). Two interventions (Magnago Lampugnani and Welch Guerra) relate this paradigm directly to urban development models, pinpointing the emerging topic of shrinking cities. There are also frequent self-criticisms and signs that the greatest conflict - or at least an important aggravation in urban contradictions - may lie in our scientific approaches, tools of analysis and stances, or even in the social role played by our disciplines (see the responses given 
by Davoudi, Garnier, Gottdiener, Krier or Portas). This perspective is taken one step further by Mazza, who considers that the situation in Italian cities is not especially conflictive or that, at least, urban planning has a very limited capacity to face conflict in the case of large cities.

The vast majority of those surveyed considered that the arenas of action for resolving these conflicts are outside their disciplinary fields and entered into wider social and political dimensions (in particular see Garnier, Goonewardena and Gottdiener) deployed in a set of scales (Pacione), but most of the responses indicate the specific, positive contributions that can be made in this respect by their respective areas. However, other participants warn about the negative effects of conventional urban studies (Garnier) or narratives (Zukin) and the short-circuiting of knowledge caused by the division of academic labor (Gottdiener). Finally, the responses were quite diverse in referring to 'best practices' in resolving or dealing with the foregoing conflicts. Some authors gave their own academic or professional production as references, while others mentioned those of colleagues; very few proposed specific plans, policies, programs or interventions as examples (Bannen, Hall, Kewalramani, Krier, Magnago Lampugnani, Muxí, Samuels, Shen) and some participants (Davis) considered that it was best not to respond to this question, an attitude that reveals an indirect criticism regarding the way in which it was formulated.

In short, there are deep coincidences in many issues and questions for concern, even with respect to how to deal with these issues, and the relative role played by certain academic and professional disciplines in such a project. Nonetheless, it is still difficult to identify specific guidelines to be adopted, common strategies that are universally valid or even isolated cases of 'best practices' that could be extended to the entire spectrum of their dimensions. It seems that there is common, implicit agreement on the need for local and particular solutions even when the conflicts at stake may present some wider and general patterns. As is to be expected, it is clear that there is still a long way to go in the different disciplines that have decided to embrace urban formations as their object of analysis, but we can certainly reduce the distance if we stop creating forks and extraneous disciplinary routes and assume the need to face the real conflicts of contemporary cities more directly and with greater cooperation. We hope that this project proves to be the beginning of wider interdisciplinary conversation among all urban disciplines.

\section{Acknowledgement}

An abridged Spanish version of this survey was published in Sevilla-Buitrago, A. (Ed.) (2012) Conflictos de la ciudad contemporánea: un sondeo internacional. Urban, new series, 3, 107-137.

\section{References}

Atkinson, A. (1996). Sustainable cities: Dilemmas and options. City, 1(3-4), 5-11. Batty, M. (2012). Building a science of cities. Cities, 29(Suppl. 1), 9-16.

Beauregard, R. (2010). Urban studies. In R. Hutchison (Ed.), Encyclopedia of urban studies (pp. 930-935). Los Angeles: Sage.

Bertho, A. (2009). Le temps des émeutes. Paris: Bayard.

Bollens, S. (2000). On narrow ground. Urban policy and ethnic conflict in Jerusalem and Belfast. Albany: State University of New York Press.

Breheny, M. (1992). Sustainable development and urban form. London: Pion.
Brenner, N., Marcuse, P., \& Mayer, M. (Eds.). (2011). Cities for people not for profit. Critical urban theory and the right to the city. London: Routledge.

Brenner, N., \& Theodore, N. (Eds.). (2002). Spaces of neoliberalism: Urban restructuring in North America and Western Europe. Oxford: Blackwell.

Cities (1996). Special issue: Green cities. Cities, 13(5), 303-372.

Cities (2011). Special issue: Low carbon cities. Cities, 28(6), 495-582.

Davies, J., \& Imbroscio, D. (Eds.). (2010). Critical urban studies. New directions. Albany: State University of New York Press.

Davoudi, S. (2006). Evidence-based planning: Rhetoric and reality. DisP, 165(2), 14-25.

Davoudi, S., \& Pendlebury, J. (2010). Evolution of planning as an academic discipline. Town Planning Review, 81, 613-644.

Davoudi, S. (2011). The legacy of positivism and the emergence of interpretive tradition in spatial planning. Regional Studies, 46, 429-441.

Davoudi, S. (2012). Climate risk and security: New meanings of 'the environment' in the English planning system. European Planning Studies, 20, 49-69.

Fainstein, S. (2010). The just city. New York: Cornell University Press.

Flint, C. (2006). Cities, war, and terrorism: Towards an urban geopolitics. Annals of the Association of American Geographers, 96, 216-218.

Garnier, J. P. (1996). Des barbares dans la cité: de la tyrannie du marché à la violence urbaine. Paris: Flammarion.

Garnier, J. P. (2010). Une violence éminemment contemporaine: Essais sur la ville, la petite bourgeoisie intellectuelle et l'effacement des classes populaires. Paris: Agone.

Girardet, H. (1992). Cities: New directions for sustainable urban living. London: Gaia Books.

Glaeser, E., \& Gyourko, J. (2005). Urban decline and durable housing. Journal of Political Economy, 113, 345-375.

Gottdiener, M., \& Hutchinson, R. (2010). The new urban sociology (4th ed.). Boulder: Westview.

Heynen, N., Kaika, M., \& Swyngedouw, E. (2006). In the nature of cities. Urban political ecology and the politics of urban metabolism. New York: Routledge.

Hubbard, P. (2006). City. London: Routledge.

INURA (International Network for Urban Research and Action) (2003). An alternative urban world is possible: A declaration for urban research and action. International Journal of Urban and Regional Research, 27, 952-955.

Krier, R. (1982). On architecture. London: Academy Editions.

Krier, R. (2003). Town spaces. Contemporary interpretations in traditional urbanism. Basel: Birkhäuser.

Le Galès, P. (2002). European cities. Social conflicts and governance. Oxford: Oxford University Press.

Logan, J. (2008). Urban China in transition. Oxford: Blackwell.

Magnago Lampugnani, V. (n.d.). Memory and critical science: Re-establishing the discipline of urban design. <http://www.stadtbaukunst.org/cms/upload/texte_zur_stadtbaukunst/Lampugnani_Memory_and_critical_science.pdf> Accessed 26.04.12.

Marcuse, P. (2009). Searching for the just city. Debates in urban theory and practice. London: Routledge.

McClain, P. (2001). Urban crime in the USA and Western Europe: A comparison. In R Paddison (Ed.), Handbook of urban studies (pp. 220-236). London: Sage.

Mazza, L. (2011). Dimensione urbana e strumenti di governo del territorio. In A Arcidiacono \& L. Pogliani (Eds.). Milano al futuro. Riforma o crisi del governo urbano (pp. 63-83). Milano et al. edizioni. <http://www.empirismoeretico.it/luigi-mazzadimensione-urbana-e-strumenti-di-governo-del-territorio> Accessed 26.04.12.

Minton, A. (2009). Ground control: Fear and happiness in the twenty-first-century city. London: Penguin.

Mitchell, D. (2003). The right to the city: Social justice and the fight for public space. New York: Guilford.

Pacione, M. (2003). Urban environmental quality and human wellbeing: A geographical perspective. Landscape and Urban Planning, 65(1-2), 19-30.

Pacione, M. (2005). Urban geography. A global perspective (2nd ed.). London: Routledge.

Paddison, R. (2001). Studying cities. In R. Paddison (Ed.), Handbook of urban studies (pp. 1-9). London: Sage.

Patel, S. (2010). The making of global city regions: Mumbai: The mega-city of a poor country. In G. Bridge \& S. Watson (Eds.), The Blackwell city reader (2nd ed. pp. 72-78). Oxford: Blackwell.

Sassen, S., \& Dotan, N. (2011). Delegating, not returning, to the biosphere: How to use the multi-scalar and ecological properties of cities. Global Environmenta Change, 21, 823-834.

Soja, E. (2010). Seeking spatial justice. Minnesota: University of Minnesota Press.

Sugrue, T. (2005). The origins of the urban crisis. Race and inequality in postwar detroit (2nd ed.). Princeton, NJ: Princeton University Press.

Urban Studies (2010). Special issue: Cities, justice and conflict. Urban Studies, 47(6), 1165-1366.

Winton, A. (2004). Urban violence. A guide to the literature. Environment and Urbanization, 16, 165-184. 